\title{
UNIVERSITYOF
}

FORWARD

THINKING

WESTMINSTER用

WestminsterResearch

http://www.westminster.ac.uk/westminsterresearch

\section{Stimulating learning about social entrepreneurship through income generation projects}

Chang, J., Benamraoui, A. and Rieple, A.

This article is (C) Emerald and permission has been granted for this version to appear here http://westminsterresearch.wmin.ac.uk/20201/

Emerald does not grant permission for this article to be further copied/distributed or hosted elsewhere without the express permission from Emerald Group Publishing Limited.

The final, published version in International Journal of Entrepreneurial Behaviour \& Research , 20 (5), pp. 417-437, 2014 is available at:

https://dx.doi.org/10.1108/IJEBR-10-2012-0111

The WestminsterResearch online digital archive at the University of Westminster aims to make the research output of the University available to a wider audience. Copyright and Moral Rights remain with the authors and/or copyright owners.

Whilst further distribution of specific materials from within this archive is forbidden, you may freely distribute the URL of WestminsterResearch: ((http://westminsterresearch.wmin.ac.uk/)).

In case of abuse or copyright appearing without permission e-mail repository@westminster.ac.uk 


\title{
Stimulating learning about social entrepreneurship through income generation projects
}

\begin{abstract}
:
Purpose - This empirical paper examines the use of income generation projects as a pedagogic method to assess students' learning about social enterprises. We are interested in how and why this innovative approach might improve students' understanding of the different aspects and attributes of social entrepreneurship.

Design/methodology/approach - our study used thematic analysis of qualitative data comprising the reflective logs of 87 students on an undergraduate entrepreneurship module in a university business programme. The major attributes of social entrepreneurship were identified from a review of literature, and we used the logs to judge whether students had learnt about these attributes.

Findings - results show that students developed an understanding concerning social enterprises' diverse stakeholder environment, market needs, social enterprises' ideological foundations, resource mobilisation processes and performance measurement - both social and financial. In addition, they developed skills in reflection and self-awareness, communication, empathy and the generation of new ideas.
\end{abstract}

Research limitations/implications - our study is limited in that it focused on only one cohort of students, undergraduates. We cannot claim that our findings are generalisable to other students or contexts.

Practical implications - students are better able to understand the needs and values of social enterprises. However, this is a resource intensive process for educators with implications for curriculum design and management.

Social Implications - This study sheds new light on how experiential learning helps to raise students' awareness of social enterprises.

Originality/value - this study sheds new light on how experiential learning in the form of income generation projects helps to raise students' awareness of social enterprises. Its value lies in helping to develop a novel and effective pedagogy for entrepreneurial learning 
Keywords: Experiential learning; learning-by-doing; social entrepreneurship; higher education pedagogy; income-generation projects

Article Type: Research paper 


\section{Introduction}

This research article examines how generating funds for social enterprises within an undergraduate business studies module enables students to understand the attributes and needs of these types of organisations. The module requires students to develop fundgenerating ideas for real social enterprises, from a zero budget, present their ideas to the social entrepreneur, and turn their plans into real fund-raising activities. This engages students in an experiential learning process that incorporates reflection.

The paper starts by evaluating experiential learning in entrepreneurship and social entrepreneurship education. We define social entrepreneurship as the creation of value with social or community goals as its base, where the profit is invested in the activity or venture rather than returned to investors (Harding, 2006, p. 5). Social enterprises are the outcome of the entrepreneurial process, the organisation created by the social entrepreneur (Brouard and Larivet, 2010). We explain how social entrepreneurship differs from normal entrepreneurship and discuss how, by generating income for the social enterprises, students are exposed to a learning environment that replicates the different concerns of these 
organisations. We then review the role of experiential learning in management education and explain how developing business ideas for social enterprises fits within this philosophy.

In the following section we describe the research design and how we analyzed the reflective logs from the 87 students in our sample. Using the rich data from the students' reflections, we evaluate and discuss the effectiveness of this form of social entrepreneurship education. The concluding section of the paper makes some recommendations for both practice and research based on the study's key findings.

\section{Experiential learning in entrepreneurship and social entrepreneurship education}

Experiential learning is a process of learning through reflection on experience. Through this process knowledge is generated. This is a powerful form of learning because it involves direct experience of the phenomenon being studied rather than simply reading or thinking about it (Kickul et al., 2010; Kolb, 1984; Tracey and Phillips, 2007), thus creating meaning from the encounter (Kolb, 1984). Types of experiential learning include internships (Severance and Starr, 2011), field placements (Elrod and Simon, 2008; Mobley, 2007), apprenticeships, as well as the one that we focus on in this study, short term 'live' projects working with 'real' people in real roles. The choice of approach depends on the types of 
learning needs or social context of the student. Apprenticeships and internships tend to last longer and thereby can cover a greater number of topics. Their length is a disadvantage, however, to students who do not want to spend a long time on one project. So there is a trade off between length and learning exposure; live projects are less comprehensive than an internship, but richer than the normal student classroom experience.

There are two main types of experiential learning environments: simulated and real life. The simulated domain includes business games and case studies, both in common use in entrepreneurship education in business schools. Pittaway and Cope (2007), however, argue that although it is possible to simulate some aspects of entrepreneurship such as emotional exposure and situated learning, this is not possible for other aspects, including the holistic entrepreneurial process and the problems that entrepreneurs face, for example resource mobilization, exposure to financial risk and performance management. Important epistemological aspects of learning are feelings and emotions (Gibb, 2002). In Gibb's view cognitive, connative and affective developments are highly driven by personal motivations and emotional intelligence, factors which are heightened in real situations.

In fact entrepreneurship education appears to be moving away from traditional classroom teaching towards more experiential forms of learning (Gibb, 2002; Rasmussen and Sørheim, 2006). This method of learning focuses on the development of an individual's 
practical skills and attributes as well as both tacit and explicit knowledge (Gibb, 1993, 2000, 2002) within real situations in which the learner is an active participant (Revans, 1982). The Global Entrepreneurship Monitor's (GEM, 2008) survey of 38 countries found that experiential learning was an effective way of developing entrepreneurs, confirmed by studies in Singapore (Tan and Ng, 2006), Finland (Heinonen et al., 2006); Norway (Lewis, 2005) and the UK (Rae, 2003). Similar studies found that participating in education programmes while working in their businesses helped entrepreneurs improve their business-related skills (Clarke et al., 2006; Raffo et al., 2000). Experiential learning is therefore a potentially important component of a social entrepreneurship curriculum (Tracey and Phillips, 2007), where learning comes about as the result of the accumulation of transforming experiences (Kolb, 1984; Politis, 2005; Rae, 2003; Sarasvathy, 2001).

A major benefit of experiential learning is the acquisition of tacit knowledge (Armstrong and Mahmud, 2008; Holcomb et al., 2009; Holman, et al., 1997; Kayes, 2002). Evidence suggests that students who have experienced start up procedures are more likely to have entrepreneurial intentions than those without prior exposure (Gibb, 1987, 2002; Peterman and Kennedy, 2003; Politis, 2008). Corbett (2005) also discovered that experiential learning facilitates the development of opportunity recognition. Focusing on social or contextual issues strongly influence the learning process (Vygotsky, 1978; Webb, 2001), and there is 
increasing recognition that experiential learning needs to be responsive to factors such as age (Truluck and Courtenay, 1999), ethnicity (Chavan, 2011), technology (Shepherd, 1998), and learning styles (Hertzog and Lieble, 1996).

One of the biggest problems with simulated learning is the absence of trade-off, the need to commit to specific courses of events and the concomitant lack of commitment to others. These are important, and tricky, features of the entrepreneur's life. Experiential learning projects can help nascent entrepreneurs to develop understanding of features such as financial risk and the importance of mobilization of resources in generating real income (HEEG, 2011; Pittaway, et al., 2011). Henson (2010) also discovered the benefits of income generating projects in improving students' professionalism in the field of IT. Projects helped to develop students' awareness of the value of money (Alsos, et al., 2006; Oxenham, et al., 2002). Experience of our own students over many years suggests that they can have a completely unrealistic approach to business finances, and that understanding the underlying principles of financial decision-making is an important thing to acquire.

Most entrepreneurship programmes engage students at classroom level, with negligible experience for students to create opportunities, or to weigh up risks in order to develop wealth (Schlee et al., 2009; Tracey and Phillips, 2007). There is almost no research on why 
and how income generating projects can be an effective method of teaching social entrepreneurship. Thus we believe that our study is timely.

\section{Defining social entrepreneurship and social enterprise}

Our study is underpinned by a belief that social entrepreneurship is different from 'normal' entrepreneurship in some ways, and that its education should cover the additional complexities that a social entrepreneur has to deal with. We argue that income generation provides one way of achieving this (Orton et al., 2007).

Social entrepreneurship, like 'normal' entrepreneurship, is a concept that has many different elements and has been defined in a myriad ways. We elect to define social entrepreneurship as the creation of organisations or institutions that have as their objective social or community benefits and where the profit is invested in the activities of the venture rather than returned to investors (Harding, 2004; 2006) or, more simply, people who develop economically sustainable solutions to social problems (Tracey and Phillips, 2007, p. 264). The social entrepreneur is the person who brings 'his or her aspiration, direct action, creativity, courage, and fortitude ... that secures permanent benefit for the targeted group and society at large' (Martin and Osberg, 2007, p. 39). Social enterprises are the outcome 
of the entrepreneurial process - the organisation created by the social entrepreneur (Brouard and Larivet, 2010).

The attributes of social entrepreneurs encompass entrepreneurial and managerial capabilities needed to bridge diverse stakeholder communities (Cope et al., 2007) as well as adaptive skills needed to manage the changing social enterprise environment. Cope et al. also note that social capital in this context entails using social connections and relationships to raise resources, both financial and non-financial - in the form of expertise, information and other provisions. Relational capital enables entrepreneurs to raise more financial and human capital than they could through using their own internal resources (Casson, 1982 and 1993; Kim and Aldrich, 2005).

An experiential learning environment provides a better opportunity for students to discover the complexities faced by social entrepreneurs and develop the necessary knowledge and skills (Lave and Wenger, 1991; Rae, 2009). This pedagogic approach exposes students to the ideology of social entrepreneurs, the factors that contribute to market failure, the resource mobilization processes, performance factors, and the need to bridge multi-level stakeholders (Alvord, et al., 2004). The behaviours that should be observed include exploring new opportunities, taking risks, commitment to work, applying intelligence and determination (Caird, 1990). 
Generating real funds for real social enterprises is a form of experiential learning in which business students, normally undergraduates who may not have been aware of the role of social enterprises or may not have considered a career as social entrepreneurs (Collins et al., 2006), can increase their understanding of the sector. In many social entrepreneurship curricula, in and out of the classroom, the pedagogy revolves around academic development - but at the level of a consultant, not a practitioner (Gunn et al., 2008; Kickul et al., 2010). The creation of a business plan, as described by Gunn et al. (2008) and Heriot et al. (2008), is usually in a shadowing role and does not give students direct experience of business development.

An experiential programme focusing on income generation needs to bring together a number of different stakeholders who bring their respective knowledge, skills, resources and experiences to the project (Boud and Costley, 2007). These stakeholders can be divided into three separate groups:

- Social entrepreneurs - who have the skills, knowledge and experience of the creation of social wealth rather than economic wealth (Mair and Marti, 2006). They have to want to share their knowledge with the students. The benefits they receive in return include the generation of funds, the 
opportunity to promote social values, as well as the ability to promote the cause of the enterprise itself.

- Facilitators - academic and non-academic staff from the university with skills, knowledge and experience in pedagogic development, project management and educational event organisation.

- Individuals and businesses within the community who are prepared to support students' efforts to raise funds by providing funding themselves, or the resources or means to help students generate the funds.

Two key assumptions underpin the notion of bringing these stakeholders together. First, principles of mutuality and reciprocity between the players bring a synergistic interaction that allows for benefits both to the enterprise and the development of students' entrepreneurial capabilities. Second, the learning environment allows for the exploration and generation of different fund-raising opportunities (Gibb, 2002 Rae, 2003, 2009;) in a relatively risk-free environment. Although risk awareness is built into the process of assessing different options, unsuccessful value creation is not penalized as it would be in real life: starting from a base of zero funds means that no money can be lost, and the assessment of performance is judged mainly on the basis of a reflective log. 


\section{The learning framework: description of the experiential learning project}

This paper reports on a study of experiential learning within an elective undergraduate module in a UK business school. The module was entitled 'Developing a Small Business', in this case a social enterprise. Ninety two students participated in the module. Students were not required to have any prior knowledge of social entrepreneurship. Eighteen teams were created from the student population and each was given the task of working with their choice of one of four social enterprises: 1) a hospice, 2) a respite centre for head injuries, 3) a charity focusing on education in Afghanistan and 4) a charity focusing on providing aid for women in South Africa. Students had to select a way of raising money for their selected social enterprise. They were allowed to discuss their ideas with programme facilitators, but had full control in executing their plans. The chosen fund-raising activities included food fairs (selling Chinese food), costume and comedy nights, salsa evenings, street collections, football competitions, charity auctions, and T-shirt sales.

A number of the pedagogical elements used in the design and the delivery of this programme were borrowed from other studies that have used experiential learning (e.g. Cope, 2003, 2005; Gibb, 2002; Pittaway et al., 2011). For example, the use of real fund raising exposes students to random events and therefore creates a challenging and dynamic atmosphere that encourages students to be adaptable and experiment (Pittaway and Cope, 
2007) in order to develop new business ideas (Gibb, 2002). The students had no prior budget for these activities, and little time to raise funds. They also had to work with different groups of people. All these factors provided a stretching and stimulating environment (Pittaway and Cope, 2007). The problems encountered forced students to reflect and find explanations for their problems - something that was also encouraged through the reflective logs that they were required to complete.

The teams had to set up an online Just Giving page ${ }^{1}$. The page was used by academic staff to monitor any updates made and assess the activities carried out by each team, and showed in real time the amount raised by the students' activities. The students also had to set up a Wiki ${ }^{2}$ link within the university's online learning environment which required students to report on their progress weekly. Weekly feedback was provided to students on their progress by the academic staff via the Wiki site.

It was expected that students would develop learning around the dimensions listed in Table 1, which describes how social entrepreneurship differs from 'normal' entrepreneurship. These provided the basis for the thematic analysis of students' logs, which they wrote up on the weekly activities listed in Table 2 .

\footnotetext{
${ }^{1}$ Just Giving is a web donation portal which manages the donation process for fund-raising causes.

${ }^{2}$ A Wiki is a collaborative learning tool, which enables students to contribute, amend, and change material on pages available via an on-line learning environment (in this case Blackboard)
} 
Insert Table 1 here: The five dimensions of social entrepreneurship

Table 2 about here: Students' Weekly Activities

The module ran over ten weeks. In week one students were introduced to the module aims and learning outcomes. They were also given information on assessment methods, how to form their groups, and the techniques that would be used to evaluate their income generation ideas. Staff from the social enterprises met the students who would work with them and presented their vision and aims. In week two the concepts of planning, organisation, exploration and business interaction were discussed with students. In this week students also visited their respective social enterprises. In week three students were briefed about the factors needed to be taken into consideration in the development of a fund-raising plan and the timescales needed, how to identify potential resources and facilities, and how to co-ordinate team roles and responsibilities. In this week students were expected to explore their initial ideas for their fund-raising plans with the social enterprises.

In week four students formally presented their fund-raising plans to the social entrepreneur. They received feedback on the viability of their ideas and were advised how they could deliver their plans successfully. In weeks five and six students were advised about their mobilisation of resources and their communication plans, and feedback given about their 
progress. In the following two weeks students had to run their fund-raising events. In week nine students made presentations on their fund-raising activities to the social enterprises. The aim of these presentations was to assess if the students had met their clients' expectations, and also to improve their presentation skills. In week ten students made their final presentation to a panel of independent business experts who judged the effectiveness of the fund-raising projects. Throughout this process the students kept individual reflective $\operatorname{logs}$ of their learning.

\section{Data collection and analysis methods}

The purpose of this research was to explore whether income generation for social enterprises is a suitable experiential learning method and, if so, how and why this approach improves students' understanding of social entrepreneurship.

The data used in the study were the students' written reflective logs (Case and Selvester, 2002; Pittaway and Cope, 2007), each of which was between 1000 and 1500 words in length. 87 out of $92(94.6 \%)$ students completed the logs and gave permission for their use in this study: $62 \%$ were male and $38 \%$ female, and from various business disciplines. Coding was undertaken using NVIVO software, using the principles of qualitative thematic analysis (Flick, 2002; Miles and Huberman, 1994). This entailed finding relevant themes in the students' logs, classifying and coding the data based on constructs derived from theory 
as well as emerging themes, and then interpreting the results. NVIVO makes this process easier through allowing the analyst to map relationships between categories and meta themes.

The principles of thematic qualitative analysis are mainly hypothetico-deductive, guided by a conceptual model derived from the literature which is then compared against the data (Braun and Clarke, 2006; Di Domenico et al. 2010). We were interested in the five key elements of social entrepreneurship (market recognition, resources mobilisation, multiple stakeholders, ideology, and performance) as shown in Tables 1 and 2. Following an analysis of the logs two of this paper's authors agreed on the codes and major themes. Both authors had worked on the early stages of the research and its design. Blind coding (Busenitz, 1999) was adopted to avoid possible bias. There was close agreement between the two coders. Categories were refined and re-described following re-reading of the logs and discussions between the authors until data saturation was achieved and the boundaries of constructs could be settled (see Table 4 below). These form the basis for the narrative in this paper.

We have had to assume that the students' accounts are an accurate reflection of their real behaviour, individually or in groups, and knowledge, before, during and after the fund raising events. It was not possible to assess if students attempted to enhance their reported 
learning 'performance' in the hope of achieving a better grade. However, although the reflective logs were assessed, their content was also placed against observations, discussions and questioning, thus any discrepancies could be identified and challenged. We believe that they are as truthful as possible. They also provided an indication of the way students felt about their learning experience and the different players involved in the programme.

\section{Findings: Narrative Coding}

Two levels of coding were used. The first explored the broad themes of social entrepreneurship theory derived from the literature review. The second identified subthemes that emerged from the students' accounts. The students were not given a totally free reign within the logs, as they had to write about what they had learnt from their experiences, and in particular their interaction with the social entrepreneur. They had also been conditioned on what to say through a lecture on the characteristics of social enterprises in which certain key themes were presented to the students, for example the importance of working with stakeholders, the process of seeking sponsorship, and the differences between a social and a 'normal' enterprise.

The results of the analysis are reported in Tables 3 and 4 . 
Insert Table 3 here: First level narrative coding

Insert Table 4 here: Second level narrative coding

Insert table 5 about here: Dimensions of Social Entrepreneurship and Supporting Evidence

\section{Discussion}

The study results reveal evidence that experiential learning is a effective approach for a social entrepreneurship module in higher education as it enables students to acquire relevant skills and attributes, including reflection (Kickul et al., 2010), conceptualising new business ideas (Gibb, 2002) , managing resources and motivating people (Pittaway et al., 2011). We looked for evidence of awareness about the five aspects of social entrepreneurship: stakeholder environment, market gap, ideology, resource' mobilisation and performance measurement. Table 3 reveals that the income generation activity 
provided a means for learning about social enterprises. Students were most aware of the need to work with a variety of stakeholders, and less aware of the need to meet both economic and social performance measures. These five aspects could be broken down into sub-categories (Table 4).

In line with the view of Schlee et al., (2009) and Tracey and Phillips (2007) that income generating projects can be an effective method of teaching social entrepreneurship, in our own study such projects gave the students the opportunity to use their own abilities and connections to seek ways of raising money for the social enterprises. Starting from a zero budget was helpful in allowing students to experience the roles played by the social entrepreneurs themselves, where they often have to rely on limited resources.

\section{Diverse stakeholder environment}

Students' accounts showed that of the five key attributes of social entrepreneurship they learned especially about the importance of the need to work with diverse stakeholders (A1$\mathbf{A 5}^{\mathbf{3}}$ ) (Sullivan-Mort et al., 2003), and work in a way that balanced their interests (Peredo and McLean, 2006).

\footnotetext{
3 These refer to the categories in Table 4
} 
The presentation of our ideas to the social enterprises, academics and business sponsors showed that business works with different types of stakeholders and for our idea to be acceptable, it must satisfy the needs of each stakeholder (Sheery ${ }^{4}$ )

Working with different people from diverse communities force me to understand people's needs and adjust to different situations so that everybody is satisfied (Winsome)

The data similarly showed that students were able to operate as bricoleurs, using whatever resources were available in order to raise funds (Baker, et al., 2003; Di Domenico et al., 2010). Many appeared adept at assembling different stakeholders in order to create appropriate products or services, sometimes offering to promote the stakeholder's products or services in exchange for sponsorship (A3 and D3). Students obtained their ideas from their peers (A1) and social entrepreneurs (A2), and received materials for their products from business sponsors, manufacturers, suppliers and student unions (A5). They were also aware of the requirement to operate within the principles of each stakeholder (C2).

${ }^{4}$ All names are anonymised 


\section{Recognition of Market Need}

Social entrepreneurship education commonly focuses on identifying the unmet needs of beneficiaries, with less emphasis placed on the different types of revenue stream available to the social enterprise $(\mathbf{C} 1)$. The income generation projects made students understand that beneficiaries do not directly buy a social enterprise's product (C3 and C5). Students also came to realise that the social enterprises were actually targeting the students themselves as their potential customers, and had become involved with the university as part of their network management processes (B2 and C5).

As we want to generate money for the social enterprise and meet its social goal, we want to make sure that there is a market need for our idea. From the primary research of our target group we discovered $78 \%$ of our responses are interested in Chinese food. Hence, we decided to organise Chinese buffet in a bar, which coincide with one of the world cup football matches (Ling).

The students were able to bring in knowledge from other modules, for example accounting and marketing, to apply to the new setting (E1 and E2):

I found several opportunities for our designated social enterprise (ACTSA) taking into account their level of risk, investment and operational costs, which then 
provided worthwhile service to the community. I also found that analysing the business environment is essential to the success of the event in terms of forecasting, eliminating possible barriers and generating economic benefits to achieve the social goal (Stephen)

From Stephen and Ling's accounts, we can see that these students used their business knowledge to ensure their projects were successful in conducting a pilot study, carrying out market research, and generating income, while also developing compassion for the social enterprise's beneficiaries (Sullivan et al., 2003; Campbell, 1998) (C2 and C4).

\section{Appreciation of Social Enterprise's Dominant Ideology}

One of the key features of social entrepreneurship is the compassion of the entrepreneur and their desire to create social change and/or to provide social benefits (Choi and Gray, 2008; Dees and Anderson, 2003; Dees, 1998). Experiencing the social enterprise's environment appears to have encouraged learning (Kickul et al., 2010) (A2, C3 and C5). Throughout the students' reflections, there was evidence of an awareness of an ideology of social concern as the prime mover for these organizations (C2 and C4). In most cases logs showed that this was an eye opener, and the experience appears to have triggered intentions towards social entrepreneurship in some students: 
I thoroughly appreciate the role played by Laura (social enterprise) and I want to contribute to this cause when I start my own business (Sooha)

It is an unforgettable experience preparing and holding an event for the social enterprise.... working with social enterprise exposed me to the concept of caring for the society which I did not experience back home (Dalian)

The first contact with the social enterprises, the commissioning of the project followed by a field visit to their premises, provided immediate evidence of the organisations' values (Kickul et al., 2010) (C2). This also made students aware that social entrepreneurship is not just about addressing the economic issues of the business but meeting the needs of beneficiaries (Hamilton, 2004; Tracey and Philips, 2007) and that can sometimes result in conflict:

Our idea of raising funds by organising bumper cars as part of the Westfair was rejected by the social enterprise as its social ethos is to rehabilitate victims with head injuries. Hence, we were obliged to revise our plan and come out with a new idea, which is not conflicting with their social values (Ben)

Students in this case were also faced with the need to be adaptable, given the rejection of their original idea (Pittaway and Cope, 2007) (B1 and B2). 


\section{Resource Mobilization}

It is more difficult to mobilize social enterprises' resources, financial and human, than those of purely business commercial entities (Austin et al., 2006) because of the social enterprise's need to pursue not only economic gain but also social benefits (Morrissette, 2007). Therefore, social entrepreneurs face many difficulties when they attempt to raise funds from 'normal' economic investors. The students' reflections confirm that they understood that social enterprises had to generate funds by looking for collaborators and accessing their trust- and reputation-based social networks (Putnam, 1995) (B3, B4 and D2).

Through learning taking place in resource-constrained environments, students realised that these organisations are working under tight resource constraints $(\mathbf{C 5})$. Students were given similar conditions as they had to start from a zero budget and use their limited resources (i.e. skills, group members, and networks) (A2 and D1):

This module has been without a doubt one of the most challenging modules I have taken during my academic time at the university. It is arguably both demanding and interesting at the same time. It certainly requires a great deal of initiative as available resources are limited (Wissy) 
The success of our group in generating income is contributed to the team and individual participation as we have set solid strategy with clear goals and tasks given to group members taking into consideration their competences, mutual trust as well as co-ordination the various tasks among the team members using effective and constant communication (Dai Lin)

The resource-constrained environment required students to pursue alternative paths to organise their fund raising events (Thompson 2002) (E1):

As the social enterprise did not have resources to help us in the comedy event, we revised our business strategy to hold the event in the campus which is sponsored by the university (Jagpal)

We weigh out the pros and cons of four ideas against the limited resources available and agreed on the Costume party which is valued as the most cost effective (Zaffran)

Attending the workshop organised by the university enterprise group on how to pitch for business sponsors has helped us in the next course of action to convince a Chinese restaurant to sponsor our fund raising event (Florence) 
Students reflections showed how they could solve problems creatively by looking for sponsors (A3 and B1) and training themselves in pitching, as emphasised by Florence's account. Working under limited resources drove the students to find other routes to make their projects work; experiences were transformed into the knowledge that resource mobilization is a challenging activity for social entrepreneurs (Anderson et al., 2006; Bornstein, 2003; Haugh, 2007).

\section{Performance measurement}

Perhaps surprisingly, performance issues were mentioned less than other issues despite the fact that the module required students to understand the social and financial aspirations of the organizations with which they were working (Choi and Gray, 2008) (B1, B3, B4 and E1). However, it was also evident that the experience of fund-raising had helped raise awareness of performance management issues:

I struggled to come out with a plan that must meet all the objectives of promoting the cause of St Luke's (Hospice) and cover its operational cost (Rafaei)

I realise that the event we ran is a pilot for the business proposal we have to produce for the next two years of the Headway. I have to come out with different types of 
revenue for the social enterprise which must cover the rehabilitation activities for its centre in East London (Jimmy)

\section{Summary and implications for theory and practice}

On the whole, our findings confirm that using fund raising activity for the social enterprises enabled students to: (1) appreciate their ideological principles; (2) understand the needs of beneficiaries; (3) mobilise limited resources; (4) work with different stakeholders; (5) understand the relevant social and economic measures that needs to be applied when evaluating the performance of social enterprises.

This paper sought to understand whether income generation projects are an effective method of teaching social entrepreneurship. Despite the spread of experiential learning in the curriculum (Oxenham, et al., 2002;), empirical work on how income generation projects can stimulate learning has been limited and uses different approaches to the one presented in this study (Alsos et al., 2006). Our study is also an answer to the critic by many scholars of the heavy reliance on face-to-face teaching in the majority of entrepreneurial education programmes (Schlee et al, 2009; Tracey and Phillips, 2007). From our data it is evident that they provide an effective method of learning and in line with the notion that experiential 
learning is an effective approach in developing future entrepreneurs (Heinonen et al., 2006; Lewis, 2005; Rae, 2003; Tan and Ng, 2006).

\section{Contribution to entrepreneurship pedagogy}

From students' reflections, a number of themes emerged that indicated increased awareness of the concerns and values of social enterprises. These included: the need to fulfil social over purely economic objectives; the different needs of beneficiaries and the sponsors that fund them, an important difference from 'normal' enterprises in which the beneficiary is also the paying customer; the pressures of coordinating a multi-stakeholder environment; the processes of resource mobilization in a resource-scarce environment; and how social enterprises face multi-performance issues, both social and economic. Knowledge attained in this respect included opportunity recognition, taking initiatives, negotiating over competing business ideas, coping with uncertainty, managing conflicts and relationships, handling emotions, assessing performance, and educating stakeholders. Much of this had aspects of tacit knowledge (Armstrong and Mahmud, 2008; Holcomb et al., 2009; Holman, et al., 1997; Kayes, 2002). 
Some of the dimensions of social entrepreneurship were mentioned more frequently than others, as shown in Tables 3 and 4: working with diverse stakeholders (28.2\%); recognition of market need (24.5\%); dominant ideology (21.8\%); resource mobilization (19.4\%); social and economic performance $(6.1 \%)$. This order appears anomalous in many ways, and we have no real explanation for this. For example, we would have predicted that resource mobilisation would have been the most mentioned, as this was the task that the students were faced with and therefore would, we believed, have been at the forefront of the students' minds. A better contextualisation of the experiential learning model using parameters such as age and ethnicity might have helped explain these anomalies (Chavan, 2011; Hertzog and Lieble, 1996; Shepherd, 1998; Truluck and Courtenay, 1999). Further research would benefit from exploring whether there is a differential effect on students' learning from the various discipline backgrounds (for example finance, marketing or human resource management) (Vygotsky, 1978; Webb, 2001). Similarly, the effects of ethnicity, age, gender, familiarity with technology, social background, and work experience are all under-researched (Chavan, 2011; Shepherd, 1998; Truluck and Courtenay, 1999). Our study had a small cohort size and a different focus, and we did not examine differences between the students. 
Another unanswered question concerns the attributes of students today and likely changes to the student of the future (Bellanca and Brandt, 2010; Dixon, 2011). Such students are likely to want to learn at a faster rate and desire quick feedback from academics about their learning. Although examining these characteristics did not form a formal part of our study, it was clear that our students reacted well to the less traditional method that they encountered. $21^{\text {st }}$ century students want to learn about theories that are relevant to their future careers, such as network building (whether 'virtual' or 'real') and the role of social responsibility and sustainability. Ethics in an open society are likely to be a major concern of future leaders, so it is arguable that working with social entrepreneurs may help to develop more rounded generic managers and employees working in profit-oriented contexts. This remains to be studied.

The use of reflective logs forces students to actively engage with thinking about what they are doing. In effect, such 'talking to oneself' formalises the process of challenging their own thinking and motivations. What emerges from this pedagogic approach is that students became more passionate about their social enterprises and remained enthusiastic about promoting their cause throughout the programme. The data indicated that many of the students felt that the experiential process was a superior type of learning compared to the traditional, didactic, forms of their normal curriculum. Their experiences engaged them, 
and when combined with the reflection, made for what appeared to be a more meaningful experience. Working with limited resources and under high level of uncertainties stimulated students to use their intellect and relationships to build capacity and transform their ideas into real income generating activities. These findings further strengthen the arguments that experiential learning provides an environment for learning about different aspects of entrepreneurship, including emotional exposure and reflection (Pittaway and Cope, 2007). Students encountered the emotional consequences of loss (of time, effort and hope), although not obviously to the same degree as a real entrepreneur would face. The process allowed students to learn from failure, and that not all ideas are workable or actionable. This helped students to learn that periods of crisis can be emotional and demanding and that they must anticipate these (Cope, 2003): they need to be flexible and adaptable. The limited resources act as the catalyst to creativity.

The reflective pedagogy enabled students to improve their critical insights into both their own performance and that of their colleagues. The need to make weekly entries into the wikis necessitated judgement of what had worked and what had not, and this provided enhanced inputs into the negotiation processes concerning what should be done next.

Students' communication abilities also improved as a result of presenting their business ideas and interacting with the various individuals involved in the fund-raising, such as the 
social entrepreneurs themselves, bankers, shopkeepers and the public. For example, students had to pitch their concepts and persuade others to buy in to their ideas and services. These results support Gibb's view (1993, 2000 \& 2002) that working in real situations is an effective way to enhance practical skills and attributes. The need to make things happen through different stakeholders fostered the development of both entrepreneurial and managerial skills (Chang and Rieple, 2013).

We do not know, however, whether students' propensity to found social enterprises is increased through this type of experience, the nature of the fund raising exercise, or whether their learning varies with the different types of social enterprise.

\section{Contribution to educational practice}

In terms of our contribution to educational practice, we believe that other higher education institutions can use our findings to inform the introduction or modification of social entrepreneurship modules. Our study demonstrated the benefits of students being exposed to the realm of social entrepreneurship through an activity taking place in a real social enterprise. However, we also highlighted how resource intensive this is, especially in terms of staff time and multi-disciplinarity. Because of the levels of student stress and discomfort there were considerable pressures on staff time; academic staff needed to adopt a different type of educational role that was closer to mentoring than lecturing. They need to hold 
multiple roles - the conventional teaching one, but also coaching, business liaison and development. Resources are also heavy in coordinating the relationships among the various stakeholders, for example the social entrepreneurs, financiers and local businesses. A number of students found the challenges of the projects difficult as it was their first experience of working in this way. If this type of teaching is to be more widely adopted, for some less confident students there may be a need to introduce interactive methods of learning activities into the 'normal' classroom in a less intensive or threatening way than the type of 'total immersion' we have described here.

In our case, some of the teaching team were experienced entrepreneurs themselves, a background that helped in negotiating access to the social entrepreneurs, but also in mentoring students about expected behaviours and potential money-raising ideas. 'Normal' academic staff are likely therefore to require specialised training in managing students' learning in an intense and ambiguous environment. Research could be extended to understand the experiences of academics in dealing with this form of pedagogy. It would also be interested in learning about the views of the social entrepreneurs and business sponsors, especially to discover if they feel such programmes are of benefit to their business goals and what types of experiences they had with the students. 
Our study has also highlighted the need for universities to be more aware of the health and safety implications of income generation projects; at the moment it is unclear who takes the responsibility had an accident taken place during one of the projects - the social enterprise, on whose behalf students are working, or the university.

\section{Conclusion}

To summarise, we could see that students were inspired by the social entrepreneurs that they worked with. Students developed empathy with their world, looked more favourably on a career as social entrepreneurs, gained better understanding of the processes of new business development, and increased their awareness and appreciation of individuals who have direct involvement in the day-to-day running of social enterprises. They also developed their abilities to recognise opportunities (Corbett, 2005) and gained the confidence that was needed to allow them to engage with social concerns. We believe that experiential methods have considerable benefits for entrepreneurial learning. 


\section{References}

Alsos, G. A., Isaksen, E. J. and Softing, E. (2006), "Youth enterprise experience and business start-up intentions", 14th Nordic Conference on Small Business Research, Stockholm.

Alvord, S. H., Brown, D. L. and Letts, C. W. (2004), "Social entrepreneurship and societal transformation”, Journal of Applied Behavioral Science, Vol. 40, pp. 260-282.

Anderson, R., Dana, L. and Dana, T. D. (2006), “Indigenous land rights, entrepreneurship, and economic development in Canada 'opting-in' to the global economy", Journal of World Business, Vol. 41, pp. 45-55.

Armstrong, S. J. and Mahmud, A. (2008), "Experiential learning and the acquisition of managerial tacit knowledge", Academy of Management Learning and Education, Vol. 7, pp. 189-208.

Austin J., Stevenson H. and Wei-Skillern J. (2006), "Social and commercial entrepreneurship: same, different, or both?", Entrepreneurship Theory and Practice, Vol. 30, pp. 1-22. 
Baker, T., Miner A. S. and Eesley, D. T. (2003), "Improvising firms: Bricolage, account giving and improvisational competencies in the founding process", Research Policy, Vol. 32, pp. $255-276$.

Bellanca, J. and Brandt R. (2010), 21st Century Skills: Rethinking How Students Learn, Solution Tree Press, Bloomington, New York.

Biggs, J., Tang, C. (2011), Teaching for Quality Learning at University, McGraw-Hill International, Maidenhead.

Bornstein, D. (2004), How to Change the World: Social Entrepreneurs and the Power of New Ideas, Oxford University Press, Oxford,

Boud, D. and Costley, C. (2007), "From project supervision to advising: new conceptions of the practice", Innovations in Education and Teaching International, Vol. 44, pp. 119130.

Braun, V. and Clarke, V. (2006), "Using thematic analysis in psychology", Qualitative Research in Psychology, Vol. 3, pp. 77-101.

Brouard, F. and Larivet, S. (2010), "Essay of clarifications and definitions of the related concepts of social enterprise, social entrepreneur and social entrepreneurship", in Fayolle, 
A. and Matlay, H. (Eds.), Handbook of Research on Social Entrepreneurship, Edward Elgar Publishing, Cheltenham and Northampton, pp. 29-56.

Bull, M. (2007), "Balance: the development of a social enterprise business performance analysis tool”, Social Enterprise Journal, Vol. 3, pp. 49-66.

Busenitz, L. W. (1999), "Entrepreneurial risk and strategic decision making: it's a matter of perspective", The Journal of Applied Behavioral Science, Vol. 35 No.3, pp. 325-340.

Caird, S. (1990), "What does it mean to be enterprising?", British Journal of Management, Vol.1,pp., 137-145.

Campbell, S. (1998), "Social entrepreneurship: how to develop new social-purpose business ventures", Healthcare Strategic Management, Vol. 16, pp. 17-18.

Case, P. and Selvester, K. (2002), "Watch your back: Reflections on trust and mistrust in management education", Management Learning, Vol. 33, pp. 231-247.

Casson, M. (1982), The Entrepreneur: An Economic Theory, Martin Robertson, Oxford. Casson, M. (1993), Entrepreneurship and business culture, in Brown, J. and Rose, M. B. (Eds), Entrepreneurship, Networks and Modern Business, Manchester University Press, Manchester, pp. 30-54. 
C.C.S.E. (2001),'Social entrepreneurship, Discussion Paper No 1", available at www.ediblestrategies.com/fsd/2001_social_entrepreneur.pdf, February (accessed 20 February 2011).

Chang, J., \& Rieple, A. (2013). "Assessing students' entrepreneurial skills development in live projects", Journal of Small Business and Enterprise Development, Vol. 20, pp. 225-241.

Chavan M. (2011), “Higher education students' attitudes towards experiential learning in international business", Journal of Teaching in International Business, Vol. 22, pp. 126143.

Choi, D.Y. and Gray, E. R. (2008), "Socially responsible entrepreneurs: what do they do to create and build their companies?", Business Horizons, Vol. 51, pp. 341-352.

Clarke, J., Thorpe, R. and Anderson, L. (2006), “It's all action, it's all learning: action learning in SMEs”, Journal of European and Industrial Training, Vol. 30, pp. 441-455.

Collins, L. A., Smith, A. J. and Hannon, P. D. (2006), “Applying a synergistic learning approach in entrepreneurship education", Management Learning, Vol. 37, pp. 335-354.

Cope J. (2003), "Entrepreneurial learning and critical reflection: Discontinuous events as triggers for higher-level learning", Management Learning, Vol. 34, pp. 429-450. 
Cope J. (2005), "Toward a dynamic learning perspective of entrepreneurship", Entrepreneurship Theory and Practice, Vol. 29, pp. 373-398.

Cope, J. Jack, S. and Rose, M. (2007), "Social Capital and Entrepreneurship: An Introduction”, International Small Business Journal, Vol. 3 No. 25, pp. 213-219.

Corbett, A. C. (2005), "Experiential learning within the process of opportunity identification and exploitation", Entrepreneurship Theory and Practice, Vol. 29, pp. 473491.

Dees J. G. (1998), “Enterprising nonprofits”, Harvard Business Review. Vol. 76, pp. 54-65.

Dees J. G. and Anderson B. (2003), "For-profit social ventures", International Journal of Entrepreneurship Education, Vol. 2, pp. 1-26.

Di Domenico, M., Haugh, H. and Tracey, P. (2010), "Social bricolage: theorizing social value creation in social enterprises", Entrepreneurship Theory and Practice, Vol. 34 No. 4, pp. $681-703$.

Dixon, P. (2011), Future Wise, Profile Books, London. 
Elrod, L. and Simon, M. (2008). “Service Learning", in Scaffolding for Successful Student Learning: Effective Practices in Using Instructional Strategies, Dietz, B. E. and Ritchey, L. H,(Eds). American Sociology Association, Washington, DC, pp. 84-110.

Flick, U. (2002), An Introduction to Qualitative Research, Sage, London.

GEM. (2008), “Global Entrepreneurship Monitor: 2008 Global Report”, available at: http:// www.GEMconsortiumorg/docs/264/gem-2008-global-report (accessed 30 May 2011).

Gibb, A. A. (1987), "Enterprise culture and its meaning and implications for education and training", Journal of European Industrial Training, Vol. 11, pp. 1-36.

Gibb, A. A. (1993), “The enterprise culture and education: understanding enterprise education and its links with small business, entrepreneurship and wider educational goals", International Small Business Journal, Vol. 11, pp. 3-32.

Gibb, A. A. (2000), "Corporate restructuring and entrepreneurship: what can large organizations learn from small? Enterprise and Innovation", Management Studies, Vol. 1, pp. 19-35. 
Gibb, A. A. (2002), "In pursuit of new enterprise and entrepreneurship paradigm for learning: creative destruction, new values, new ways of doing things and new combinations of knowledge", International Journal of Management Reviews, Vol. 4, pp. 233-269.

Gunn, R., Durkin, C. and Singh G. (2008), "Social entrepreneurship in the social policy curriculum", Social Enterprise Journal, Vol. 4, pp. 74-80.

Hamilton, E. (2004), Socially situated entrepreneurial learning in family business, 27th ISBE National Small Firms Policy and Research Conference, Newcastle.

Harding, R. (2004), "Social enterprise: the new economic engine?", Business Strategy Review, Vol. 15 No. 4, pp. 39-43.

Harding, R. (2006), Social Entrepreneurship Monitor, Global Entrepreneurship Monitor, London.

Haugh, H. (2007), “Community-led social venture creation”, Entrepreneurship Theory and Practice, Vol. 31, pp. 161-182.

HEEG. (2011), "An exploration of the use of student-run, real businesses in the South East Region, the UK and internationally for all or part of the award of a university degree", Surrey HEEG project final report, February 2011. 
Heinonen, J. and Poikkijoki, S. A. (2006), “An entrepreneurial-directed approach to entrepreneurship education: mission impossible?", Journal of Management Development, Vol. 25, pp. 80-94.

Henson, K. (2010), "Student projects as a funding source", Journal of Information Systems Educators, Vol. 21, pp. 291-298.

Heriot, K. C., Cook, R. G. and Simpson L. (2008), “The use of micro student consulting projects as an alternative traditional field-based student consulting projects: An exploratory study”, Journal of Entrepreneurship Education, Vol. 11, pp. 59-74.

Hertzog, C. J. and Lieble, C. (1996), “A study of two techniques for teaching introductory geography: traditional approach versus cooperative learning in the university classroom", Journal of Geography, Vol. 95, pp. 274-280.

Holcomb, T. R, Irel, R. D. and Holmes, R. M. J. (2009), “Architecture of entrepreneurial learning: exploring the link among heuristics, knowledge, and action”, Entrepreneurship Theory and Practice, Vol. 33, pp. 167-192.

Holman, D., Pavlica, K. and Thorpe, R. (1997), "Rethinking Kolb's theory of experiential learning: The contribution of social constructivism and activity theory", Management Learning, Vol. 8, pp. 135-148. 
Kayes, D. C. (2002), "Experiential learning and its critics: Preserving the role of experience in management learning and education", Academy of Management Learning and Education, Vol. 1, pp. 137-149.

Kim, P. H. and Aldrich, H. E. (2005), "Social capital and entrepreneurship", Foundations and Trends in Entrepreneurship, Vol. 1, pp. 1-52.

Kickul, J., Griffiths, M. and Bacq, B. (2010, “The boundary-less classroom: Extending social innovation and impact learning to the field", Journal of Small Business and Enterprise Development, Vol. 17, pp. $652-663$.

Kolb, D. A. (1984), Experiential Learning, Englewood Cliffs, Prentice-Hall, NJ.

Lave, J., and Wenger, E. (1991). Situated learning: Legitimate peripheral participation. Cambridge University Press, UK

Leadbeater, C. (1998), The Rise of the Social Entrepreneur, Demos, Britain.

Lehner, O. M. and Kansikas, J. (2012), "Opportunity Recognition in Social Entrepreneurship A Thematic Meta Analysis", Journal of Entrepreneurship, Vol. 21 No. 1, pp. 25-58.

Lewis, K. (2005), "The best of intentions: future plans of Young Enterprise Scheme participants", Education and Training, Vol. 47, pp. 470-483. 
Mair, J. and Marti, I. (2006), "Social entrepreneurship research: a source of explanation, prediction, and delight", Journal of World Business, Vol. 41, pp. 36-44.

Martin, R. L. and Osberg, S. (2007), "Social entrepreneurship: the case for definition", Stanford Social Innovation Review, Spring Issue, pp. 29-39.

Miles, M. and Huberman, A. M. (1994), "Qualitative data analysis", An expanded sourcebook, Thousand Oaks, CA.

Mobley, C. (2007), "Breaking ground engaging undergraduates in social change through service learning". Teaching Sociology, Vol.35, pp, 125-137.

Morrissette, S. G. (2007), “A profile of angel investors”, Journal of Private Equity, Vol. 10, pp. 252-266

Orton, S., Umble, K. and Zelt S. (2007), "Management academy for public health: creating entrepreneurial managers", American Journal of Public Health, Vol. 97, pp. 601-605

Oxenham, J. A., Diallo, A. and Katahoire, A. (2002), "Skills and literacy training for better livelihoods: a review of approaches and experiences”, World Bank, Washington, D.C.

Peredo, A. M. and McLean, M. (2006), "Social entrepreneurship: a critical review of the concept", Journal of World Business, Vol. 41, pp. 56-65. 
Peterman, N. and Kennedy, J. (2003), "Enterprise education: Influencing students, perceptions of entrepreneurship", Entrepreneurship Theory and Practice, Vol. 28, pp. 129144.

Pittaway, L. and Cope, J. (2007), “Simulating entrepreneurial learning: Assessing the utility of experiential learning designs", Management Learning, Vol. 38, pp. 211-233.

Pittaway, L., Rodriguez-Falcon, E. and Aiyegbayo, O. (2011), "The role of entrepreneurship clubs and societies in entrepreneurial learning", International Small Business Journal, Vol. 29, pp. 37-57.

Politis, D. (2005), “The process of entrepreneurial learning: a conceptual framework”, Entrepreneurship Theory and Practice, Vol. 29, pp. 399-424.

Politis, D. (2008), "Business angels and value added: What do we know and where do we go?" Venture Capital, Vol. 10, pp. 127-147.

Putnam, R. D. (1995), “Bowling alone: America's declining social capital”, Journal of Democracy, pp.1-5.

Rae, D. (2003), “Opportunity centred learning: an innovation in enterprise education?”, Education and Training, Vol. 45, pp. 542-549. 
Rae, D. (2009), "Connecting entrepreneurial and action learning in student-initiated new business ventures: the case of SPEED”, Action Learning Research and Practice, Vol. 6, pp. 289-303.

Raffo, C., O’Connor, J. and Lovatt, A. (2000), “Attitudes to formal business training and learning amongst entrepreneurs in the cultural industries: Situated business learning through doing with others" British Journal of Education and Work, Vol. 13, pp. 215-230.

Rasmussen, E. and Sørheim, R. (2006), “Action-based entrepreneurship education”, Technovation, Vol. 26, pp. 185-194.

Revans, R. (1982), The Origins and Growth of Action Learning, Chartwell-Bratt, London.

Sarasvathy, S. D. (2001), "Causation and effectuation: toward a theoretical shift from economic inevitability to entrepreneurial contingency", The Academy of Management Review, Vol. 26, pp. 243-263.

Schlee, R. P., Curren, M. T. and Harich, K. T. (2009), "Building a marketing curriculum to support courses in social entrepreneurship and social venture competitions", Journal of Marketing Education, Vol. 31, pp. 5-15. 
Severance, T. A., and Starr, P. J. (2011). "Beyond the classroom internships and students with special needs", Teaching Sociology, Vol.39, pp. 200-207.

Shepherd, I. (1998), Teaching and Learning Geography with Information and Communication Technologies, UK Geography Discipline Network, Cheltenham and Gloucester College of Higher Education, Cheltenham.

Smallbone, D., Evans, M., Ekanem, I. and Butters S. (2001), Researching social enterprise: Final report to the small business service, Centre for Enterprise and Economic Development Research, Middlesex University Business School, London, available at: http://www.bis.gov.uk/files/file38361.pdf (accessed 20 April 2011).

Sullivan-Mort, G., Weerawardena, J. and Carnegie, K. (2003), "Social entrepreneurship: Towards conceptualisation", International Journal of Nonprofit and Voluntary Sector Marketing, Vol. 8, pp. 76-88.

Tan, S. and Ng, C. (2006), "A problem-based learning approach to entrepreneurship education", Education and Training, Vol. 48, pp. 416-428.

Thompson, J. L. (2002), “The world of the social entrepreneur”, The International Journal of Public Sector Management, Vol. 15, pp. 412-431. 
Tracey, P. and Phillips, N. (2007), "The distinctive challenge of educating social entrepreneurs: a postscript and rejoinder to the special issue on entrepreneurship education", Academy of Management Learning Education, Vol. 6, pp. 264-271.

Truluck, J. E. and Courtenay, B. C. (1999), "Learning style preferences among older adults", Educational Gerontology, Vol. 25, pp. 221-236.

Urban, B. (2008), "Social entrepreneurship in South Africa: Delineating the construct with associated skills", International Journal of Entrepreneurial Behaviour \& Research, Vol. 14 , pp. 346-364.

Vygotsky, L. (1978), Interaction between Learning and Development, Harvard University Press, Cambridge.

Webb, M. (2001), A Definitive Critique of Experiential Learning Theory, Case Western Reserve University, USA. 